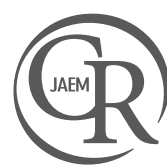

\section{Fatal Rectal Perforation Following Double Contrast Barium Enema}

\author{
Çift Kontrastlı Barium Enema Sonrası Ölümcül Rektum Perforasyonu
}

Serhat Akay ${ }^{1}$, Huriye Akay ${ }^{1}$, Mustafa Yeşil ${ }^{2}$

'Clinic of Emergency Medicine, Izmir Bozyaka Training and Research Hospital, Izmir, Turkey 2Department of Radiology, Faculty of Medicine, Dokuz Eylül University, Izmir, Turkey

\section{ABSTRACT}

Double-contrast barium enema (DCBE) is a widely used diagnostic tool for colorectal disorders, providing a relatively cheap and less invasive alternative to invasive procedures such as colonoscopy. Complications due to DCBE can be fatal in a small number of cases. Rectal perforations to the intra-peritoneal or retro-peritoneal space are the most severe and life-threatening complications where immediate diagnosis and treatment are essential. We report the case of a 72-year-old male admitted to the emergency department with dyspnea, altered mental status and swelling in the neck 15 minutes after DCBE. Upright chest X-ray revealed sub-diaphragmatic air with subcutaneous emphysema, and computed tomography revealed air in the deep neck tissue and abdominal cavity, accompanied by pneumothorax and pneumomediastinum. This case demonstrates the importance of chest pain, neck swelling and neurological symptoms after DCBE as signs of possible serious complications that should alert emergency physicians.

Keywords: Abdominal pain, radiology, intestinal perforation, rectum, retropneumoperitoneum

Received: 02.12.2011 Accepted: 09.01.2012

\section{ÖZET}

Çift kontrastlı kolon grafisi (ÇKKG), kolonoskopiye göre daha az invazif ve ucuz olan, kolorektal bozuklukların tanısında sık kullanılan bir tanısal araçtır. ÇKKG komplikasyonları az da olsa mortalite görülmektedir. İntraperitoneal ve retroperitoneal alana olan rektal perforasyonlar en ciddi komplikasyonlardır ve hızı tanı ve tedavi gerektirmektedir. Biz olgumuzda ÇKKG uygulamasından 15 dakika sonra acil servise dispne, bilinç bozukluğu ve boyunda şişme ile başvuran 72 yaşında bir erkek hastayı sunduk. Posteroanterior akciğer grafisinde subkutan amfizem ile subdiafragmatik hava ve bilgisayarlı tomografide derin boyun dokularında, abdominal kavitede hava ile pnömotoraks ve pnömomediastinum saptandı. Bu olgu, ÇKKG sonrası gelişen göğüs ağrısı, boyunda şişlik ve nörolojik bulguların ciddi komplikasyon bulguları olduğunu acil servis hekimlere hatırlatmalıdır.

Anahtar Kelimeler: Karın ağrısı, radyoloji, intestinal perforasyon, rektum, retropnömoperitonium

Geliş Tarihi: 02.12.2011 Kabul Tarihi: 09.01.2012

\section{Introduction}

Double-contrast barium enema (DCBE) is a widely used diagnostic tool for colorectal disorders, and is less expensive and relatively non-invasive compared to colonoscopy. DCBE is still accepted as the technique of choice for screening for colorectal cancer in patients with risk factors or symptoms, especially when appropriate equipment and personnel are unavailable for colonoscopy and the cost-benefit ratio is a concern. Barium, used in DCBE, is a silver-white compound that outlines the colon and rectal wall on $X$-ray and is used for the detection of filling defects and other abnormalities. While it is a relatively less invasive procedure, complications can occur during and after DCBE, among which are cardiac and cerebrovascular incidents. However, the most important and life-threatening complication of DCBE is rectal perforation, which is caused by air used for insufflation of the rectum and the colon during the procedure to enhance imaging. Such a complication has a high morbidity and mortality rate.

In this report, we describe a case seen in the Emergency Department (ED) after DCBE, with clinical and radiographic findings consistent with rectal perforation, pneumoperitoneum, pneumoretroperitoneum, pneumothorax, pneumomediastinum and extensive subcutaneous emphysema. 


\section{Case Report}

A 72-year-old male was transferred to the university ED from a regional hospital with complaints of dyspnea and altered consciousness. The patient was referred to the regional hospital after having DCBE performed as an outpatient procedure at a private clinic for differential diagnosis of constipation. Fifteen minutes after the procedure, he developed dyspnea, swelling in the neck and diffuse abdominal pain. The upright chest X-ray taken immediately after the procedure showed extensive subcutaneous emphysema with sub-diaphragmatic air on the right and the upright abdominal X-ray showed irregularities at the ampulla recti and barium residuals at colonic segments in the absence of air. The patient was transferred to a regional hospital, where rectal perforation was suspected with bilateral pneumothorax. Bilateral chest tubes were placed and the patient was transferred to a university hospital ED for further care. His medical history showed hypertension controlled with the calcium channel blocker amlodipine.

The patient was observed to exhibit altered consciousness at admission. His blood pressure was within the normal range; however, he had tachypnea with a respiratory rate of 36 breaths per minute. Breath sounds were decreased bilaterally. On palpation, subcutaneous emphysema was detected, extending from the mandible to the thoracoabdominal wall and the scrotal region. The abdominal wall was diffusely tender to palpation with diffuse guarding. A bloody fluid was detected upon digital examination of the rectum.

Biochemistry and CBC were normal. Upright chest X-ray performed at the ED showed sub-diaphragmatic air. Computed tomography imaging of the neck, thorax and abdomen revealed air in the deep neck tissue and abdominal cavity, with pneumothorax and pneumomediastinum (Figure 1). After consultation with general surgery, the patient was transferred to the operating room for explorative laparotomy. During the surgery, the mesocolon of the sigmoid was found to be filled with air. No intraperitoneal barium residuals were detected. Further examination revealed a perforation in the retroperitoneal region of the rectum and $300 \mathrm{~mL}$ of barium enema were excavated from the left fascia of Todd. Post-surgery, the patient was admitted to the intensive care unit; however, he died 20 hours after surgery due to cardiopulmonary arrest.

\section{Discussion}

Since Himmelman reported the first case of barium enema extravasation and peritoneal reaction in 1932, rectal perforation following double-contrast barium enema (DCBE) has become the most-feared complication (1). Although the real incidence of complications following DCBE is not available, a study that surveyed 409 radiographers who performed approximately 348.000 barium enema examinations reported 89 complications. The study revealed that 24 cases were due to intraperitoneal perforations, of which two patients died due to further complications (2). The frequency of perforations in this study was 1 in 14.500 .

Two different mechanisms for perforation have been described by De Feiter et al. (3). The most common mechanism is the high in-

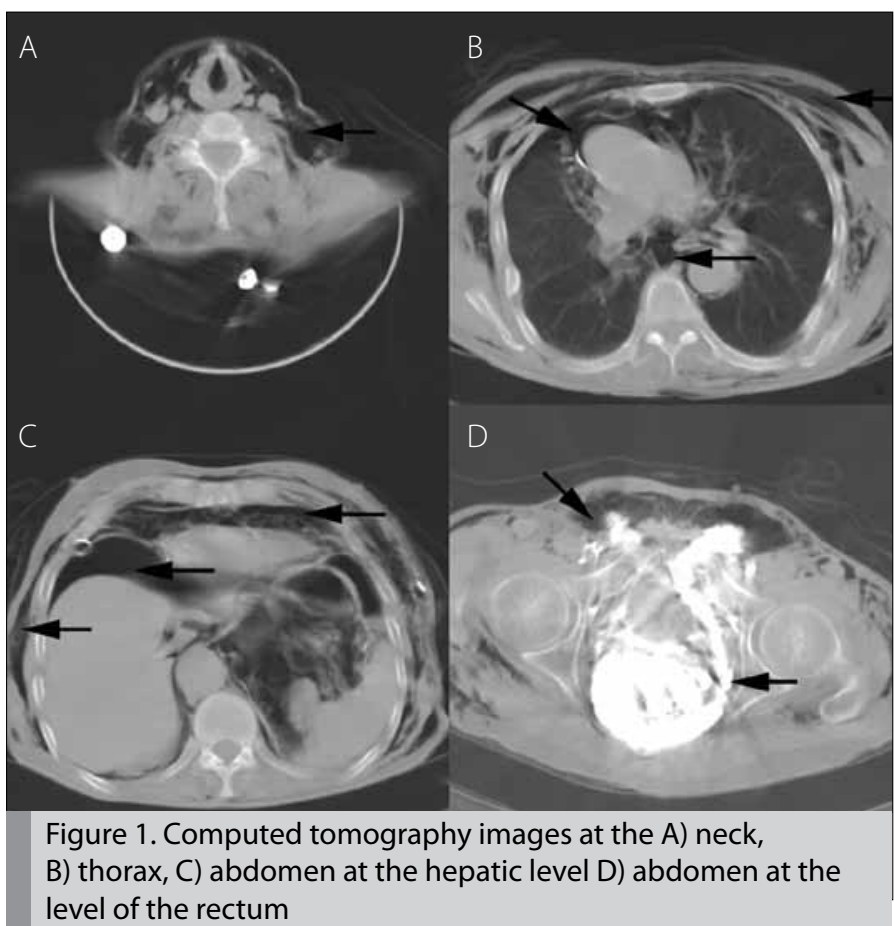

sertion of the rigid catheter and excessive inflation of the catheter balloon, which in turn might lead to the perforation of the more vulnerable anterior part of the rectum. The second mechanism is perforation due to a weakened colonic mucosa secondary to obstruction, diverticulitis, ischemic colitis, recent biopsies or old age, which are more common in patients who undergo DCBE.

Different types of perforation have been described in the literature. One study classifies the perforation as either intramural (incomplete) or extramural (complete) (2). Peterson et al. (4) divided perforations into five categories: 1) perforations of the anal canal below the levator ani muscle, 2) incomplete perforations such as perforation of the rectal mucosa, 3) perforations into the retroperitoneum, 4) transmural perforations into the adjacent viscera and 5) perforations into the free intraperitoneal cavity. The clinical signs, radiological findings, treatment strategies and prognosis may vary in each category. Our case was unique in the way that the perforation into the retroperitoneum and into the free intraperitoneal space had occurred simultaneously. Retroperitoneal perforation with sufflation of excess air led to generalized subcutaneous emphysema with pneumomediastinum and pneumothorax, which resulted in dyspnea and altered mental status.

Our case study shows that pain during or after a DCBE procedure must alert the physician to the possibility of perforation. Although the pain is expected to be intense, in some cases, pain can be minimal or might be delayed for as long as one week due to the poor sensitivity of the rectal mucosa $(5,6)$. Careful inspection of the DCBE radiographs for sub-diaphragmatic air or extravasation of the contrast medium in patients with similar complaints is suggested to rule out or diagnose perforation, which requires intervention in an expedited fashion to decrease morbidity and mortality. 
Rectal bleeding was a physical sign in our case, which increases the probability of a perforation. Tachycardia and hyperthermia might develop within a few hours of perforation as early signs of chemical peritonitis. While these signs might be subtle, the absence of these does not exclude perforation.

Surgery is the definitive course of action for intraperitoneal perforation or considerable extraperitoneal leaks where the diagnosis is definitive. If intramural or small retroperitoneal leaks are suspected, the patient may be managed conservatively with bowel rest, total parenteral nutrition, intravenous fluid support and antibiotic treatment $(7,8)$. In some cases, perirectal, mediastinal or cervical emphysema may be diagnosed days after the procedure, where patients might have mild complaints. In such cases, the patients usually relate these symptoms of perforation to an underlying medical condition and fail to seek medical advice, which can further contribute to the morbidity and mortality rates. While the mortality rate has decreased from 50\% to 35\% due to advances in medical care, transmural or intraperitoneal perforations, neglected cases, gross barium extravasation or venous intravasation are associated with increased mortality $(9,10)$.

\section{Conclusion}

As colonic imaging techniques have advanced with increased utilization of colonoscopy and computed tomography colonoscopy, perforations after DCBE has become less frequently observed. However, for patients presenting to the ED after DCBE with complaints ranging from rectal bleeding and diffuse abdominal pain to altered mental status, perforation should be highly suspected. Immediate diagnosis and treatment are essential for preventing morbidity and mortality.

\section{Conflict of interest}

No conflict of interest was declared by the authors.

\section{References}

1. Himmelmann W. Ueber. die Perforation im Bereich des Magen-Darmtraktus bei und nach der Rontgenbreipassage. Munch Med Wochenschr 1932; 79: 1567-71

2. Vora P, Chapman A. Complications from radiographer-performed double contrast barium enemas. Clin Radiol 2004; 59: 364-8. [CrossRef]

3. de Feiter PW, Soeters PB, Dejong $\mathrm{CH}$. Rectal perforations after barium enema: a review. Dis Colon Rectum 2006; 49: 261-71. [CrossRef]

4. Peterson N, Rohrmann CA Jr, Lennard ES. Diagnosis and treatment of retroperitoneal perforation complicating the double-contrast bariumenema examination. Radiology 1982; 144: 249-52.

5. Ault GW. Perforation of the rectum with enema tips. Transactions of the Annual Meeting of the American Proctologic Society 1939; 40: 203-11.

6. De Feiter PW, Soeters PB, Dejong CH. Biphasic development of an intraperitoneal rectum perforation: a rare but serious complication after barium enema. Int J Colorectal Dis 2007; 22: 719-21. [CrossRef]

7. Weiss $Y$, Grunberger P, Aronowitz S. Asymptomatic rectal perforation with retroperitoneal emphysema. Dis Colon Rectum 1981; 24: 545-7 [CrossRef].

8. Tadros S, Watters JM. Retroperitoneal perforation of the rectum during barium enema examination. Can J Surg 1988; 31: 49-50.

9. Terranova O, Meneghello A, Battocchio F, Martella B, Celi D, Nistri R. Perforations of the extraperitoneal rectum during barium enema. Int Surg 1989; 74: 13-6.

10. Hakim NS, Sarr MG, Bender CE, Nivatvongs S. Management of barium enema-induced colorectal perforation. Am Surg 1992; 58: 673-6. 